\title{
G rowth of swimming muscles and its metabolic cost in larvae of whitefish at different temperatures
}

\author{
R. H ANEL ${ }^{*}, J . K$ ARJALAINEN† AND W. W IESER ${ }^{*} \ddagger$ \\ *Institut für Z oologie, U niversität Innsbruck, T echnikerstrasse 25, A-6020 Innsbruck, \\ A ustria and †Karelian Institute, University of J oensuu, POB 111, FIN-80101 J oensuu, \\ Finland
}

(Received 12 J une 1995, A ccepted 19 A ugust 1995)

\begin{abstract}
The temperature relationship of routine metabolic rate $\left(R_{r}\right)$ of non-feeding, non-growing Coregonus lavaretus larvae between 2 and $15^{\circ} \mathrm{C}$ is characterized by $Q_{10}$-values ranging from 1.8-2.45. The rate of growth, based on weight determinations, of first-feeding larvae amounted to $3 \cdot 5,7 \cdot 6$ and $9.4 \%$ day ${ }^{-1}$ at 5,10 and $12^{\circ} \mathrm{C}$ respectively, from which $Q_{10^{-}}$values between 4.0 and 4.8 can be calculated. The rate of increase of muscle mass between 5 and $10^{\circ} \mathrm{C}$, based on the determination of the cross-sectional area of inner muscle fibres, resulted in a $Q_{10}$-value of 4.5. Water temperature influenced the pattern of growth of the inner muscle fibres. At hatching, after 360 day degrees, total muscle mass of larvae reared at 4 and $8^{\circ} \mathrm{C}$ was independent of temperature, but at $4^{\circ} \mathrm{C}$ the rate of mass increase owed more to hyperplasia (increase in fibre number) than to hypertrophy (increase in fibre mass), whereas at $8^{\circ} \mathrm{C}$ the opposite was the case. The calculation of power budgets (including the metabolic cost of growth) of first-feeding larvae yielded net conversion efficiencies $\left(\mathrm{K}_{2}\right)$ increasing with temperature from $46 \cdot 3 \%$ at $5^{\circ} \mathrm{C}$ to $54.7 \%$ at $12^{\circ} \mathrm{C}$. Comparing our data with literature data two general conclusions can be drawn. (1) In first-feeding larvae the net, but not the gross, conversion efficiency of food energy increases with temperature. This is due to net energy input being characterized by a much higher $Q_{10}$-value than energy expenditures. (2) In embryos of freshwater fish so far investigated hyperplasia plays a greater role in the increase of fibre mass than hypertrophy at the lower temperature, whereas in embryos of marine fish hyperplasia prevails at the higher temperature. It is suggested that this discrepancy correlates with the high concentration of free amino acids in the eggs of marine species which provide an additional, easily available, source of metabolic energy absent in freshwater species.
\end{abstract}

(C) 1996 The Fisheries Society of the British Isles

K ey words: oxygen consumption; growth; metabolic cost of growth; hyperplasia; hypertrophy; conversion efficiency; temperature relationships; embryos; larvae.

\section{INTRODUCTION}

The precise shape of the temperature relationship of complex physiological functions depends on many factors and their interactions. The ensuing heterogeneity of temperature-specific patterns in poikilothermic animals has been discussed by Wieser (1973) and others, but our understanding of its causes, phenotypic and genotypic, is still quite poor. The following two patterns of temperature relationship have been observed frequently. (1) $Q_{10}$-values of biological rates may differ greatly over the temperature range of a species; often they are high towards the lower end of the range but low in the zone of thermal preference. (2) In one and the same individual different functions, or components of functions, may be characterized by different temperature relationships.

$\ddagger$ A uthor to whom correspondence should be addressed. T el.: +43-512-507-6181; fax: +43-512-507-2930. 
This leads to complex relationships of derived properties, like measures of efficiency. Actually, pattern number 1 may be the consequence of pattern number 2, but it is usually difficult to establish the connection between the two.

In this paper we address the problem of the temperature relationship of growth rate and growth efficiency in fish, with particular reference to fast-growing larvae. In reviews on growth and energetics in fish one often finds the generalized statement that the functional relationship between temperature and gross growth efficiency, i.e. $P_{\text {som }} / C$, or $K_{1}$ according to I vlev (1945), where $P_{\text {som }}$ is rate of growth and $C$ the rate of ingestion, can be represented by an asymmetric bell-shaped curve with the maximum somewhere in the upper half of the biokinetic temperature range of the species (Elliott, 1976; Brett, 1979; Brett \& G roves, 1979; Wootton, 1990; Jobling, 1994). The steep increase of this function in the lower temperature range is due to the fact that the maximum rate of energy input, $C_{\text {max }}$, rises more steeply with temperature than the maintenance rate of energy expenditure $\left(R_{m}\right)$, causing an increase of the scope for growth (Brett, 1976; Kamler, 1992). The decrease of the function in the upper temperature range is due to $C_{\max }$ reaching a ceiling value at a lower temperature, and dropping more steeply, than $R_{m}$.

It is somewhat unexpected that this textbook generalization about the effects of temperature on energy allocation in fish does not appear to hold for embryos and larvae. In two recent reviews on the energetics of fish larvae (H oude, 1989; Houde \& Zastrow, 1993) earlier speculations were confirmed that at this stage gross conversion efficiency, i.e. $\mathrm{K}_{1}$, is independent of water temperature. On the other hand, since in larvae assimilation efficiency was found to decline with temperature the average net conversion efficiency, i.e. $\mathrm{K}_{2}$, is a positive function of water temperature.

This is an important finding since it allows us to discern, within the repertoire of metabolic strategies directing the acquisition and allocation of food energy in fish, the blueprint of an ontogenetic switch: in adults the mechanisms concerned with food uptake and resorption are capable of responding to an increase of temperature by accelerating the rate of energy input (C) beyond that of maintenance expenditure $\left(R_{m}\right)$. In larvae, however, the responses of food uptake to changes in water temperature appear to be more constrained so that the temperature coefficient of energy input does not exceed that of expenditures.

Confirmation of this speculation is highly desirable. Since the efficiency ratios calculated by Houde (1989) and H oude \& Zastrow (1993) are based on scattered literature data of different origin and uneven quality it seems imperative to determine the major components of energy budgets of fish larvae at different water temperatures in defined populations and under conditions which allow the simultaneous determination of rates of growth and of energy expenditure (W ieser, 1994, 1995).

Our contribution to this topic arose from the possibility of measuring, at a range of temperatures, rates of oxygen consumption, rates of growth, and rates of muscle differentiation, in larvae of the whitefish Coregonus lavaretus (L .). In combination with recent considerations on the cost of growth (W ieser, 1994), we are able to provide new information on the temperature dependence of both energy allocation and muscle growth in small-sized, fast-growing fish. We can 
show that in this species somatic production responds much more strongly to an increase of temperature than metabolic expenditures for maintenance. Our conclusions are strengthened by the fact that somatic production was established in two independent ways: by measuring (1) the rate of increase of body mass and (2) the rate of increase of the cross sectional area of the swimming muscles.

\section{MATERIALS AND METHODS}

\section{$\mathrm{FISH}$}

A rtificially fertilized eggs from two populations of whitefish were used as the source for the embryos and larvae studied in this investigation. One batch of eggs originated in Lake Pyhäselkä, eastern Finland, the other in Lake Constance at the border between A ustria, Germany and Switzerland. The eggs of both populations were transferred to Innsbruck where they were reared in the aquarium of the Institute of Zoology. In none of the subsequent studies did we observe morphological or physiological differences between the two populations. Eggs were incubated in holding tanks at 4 and $8^{\circ} \mathrm{C}$ until hatching. A fter hatching the larvae were transferred to aquaria in which the temperature had been raised to 5 and $10^{\circ} \mathrm{C}$ respectively. A third group, taken from the $8^{\circ} \mathrm{C}$ holding tank, was transferred to $12^{\circ} \mathrm{C}$. The larvae were fed once every hour with A rtemia nauplii dispensed by an automatic feeding system. Throughout the investigation mortality of embryos and larvae was very low.

\section{RESPIROMETRY}

$R$ ates of oxygen consumption were measured at a series of temperatures with the intermittent respirometer system described previously (F orstner, 1983; Wieser et al., 1988). Two three-chamber systems were available, so that up to six parallel runs on aliquot groups of larvae could be performed per day. Chamber volumes used were 79-89 and $139-167 \mathrm{~cm}^{3}$ for the measurements of yolk-sac and feeding larvae respectively. The number of larvae per chamber varied from 300 (yolk-sac at $2^{\circ} \mathrm{C}$ ) to 10 (largest feeding larvae at $12^{\circ} \mathrm{C}$ ). Y olk-sac larvae [average body weight $4 \cdot 8-6 \cdot 1 \mathrm{mg}$ wet body mass (WBM )] were measured at 2, 8, 10 and $12^{\circ} \mathrm{C}$; feeding larvae (11-3-300 $\mathrm{mg} \mathrm{WBM}$ ) at 4, 8, 10 and $12^{\circ} \mathrm{C}$. In accordance with previous studies (Wieser \& M edgyesy, 1990a,b), the mass-specific routine rate of metabolism of the larvae proved to be nearly massindependent within the mass range studied (e.g. at $10^{\circ} \mathrm{C}: \mathrm{b}=-0.023 \pm 0.042$ s.e.). In consequence, no correction for differences in body mass were applied. G roups of larvae were taken from the rearing temperatures of 5 and $10^{\circ} \mathrm{C}$ and transferred to the experimental temperatures in steps not exceeding $3^{\circ} \mathrm{C}$ day ${ }^{-1}$. We never observed differences in rates between fish acclimated to 5 or $10^{\circ} \mathrm{C}$, thus no compensatory metabolic adjustments seem to have played a role in these fish. Before the beginning of the measurements larvae were deprived of food for 8-20 h depending on temperature and size. Experimentally determined evacuation rates were used for the calculation of fasting periods (K arjalainen et al., 1991). In each chamber oxygen consumption was measured intermittently $15 \mathrm{~min} \mathrm{~h}^{-1}$ for one whole day. The values reported in Table I represent means and S.D. of the 24-hourly values, each of which resulted from extrapolating the 15 -min readings to the full hour. Oxygen consumption of the experimental system without fish was determined at the beginning and at the end of each run. The respirometer systems were cleaned and disinfected every week.

\section{SAM PLING PROTOCOL}

For the determination of total length, wet and dry body mass, random samples of about 10 larvae acclimated to 5,10 and $12^{\circ} \mathrm{C}$ were taken at the beginning and the end of the experiment. For the morphometry of swimming muscles, larvae acclimated to 4 and $8^{\circ} \mathrm{C}$ (from eye stage to hatching) or 5 and $10^{\circ} \mathrm{C}$ (from hatching to end of experiment) 
TABLE I. Routine metabolic rate $\left(R_{r}\right)$ in yolk-sac stage (4.8$6 \cdot 1 \mathrm{mg} \mathrm{WBM})$ and feeding larvae (11.3-300 mg WBM) of C. lavaretus measured at a range of temperatures

\begin{tabular}{|c|c|c|c|c|c|c|}
\hline \multirow{2}{*}{$\mathrm{T}\left({ }^{\circ} \mathrm{C}\right)$} & \multicolumn{3}{|c|}{$\begin{array}{l}\text { Y olk-sac stage } \\
\left(g W^{-1} h^{-1}\right)\end{array}$} & \multicolumn{3}{|c|}{$\begin{array}{l}\text { F eeding larvae } \\
\left(\mathrm{g} \mathrm{WBM}^{-1} \mathrm{~h}^{-1}\right)\end{array}$} \\
\hline & $\mu \mathrm{mol} \mathrm{O}_{2}$ & $J$ & $\mathrm{n}$ & $\mu \mathrm{mol} \mathrm{O}_{2}$ & J & $n$ \\
\hline $\begin{array}{l}2 \\
4\end{array}$ & $5.2(0.9)$ & $2.3(0.4)$ & 3 & & & \\
\hline $\begin{array}{l}4 \\
8\end{array}$ & $11.7(1.2)$ & $5.3(0.5)$ & 9 & $\begin{array}{l}10.2(0.5) \\
12.3(0.8)\end{array}$ & $\begin{array}{l}4.6(0.2) \\
5.5(0.4)\end{array}$ & \\
\hline 10 & $15.3(0.7)$ & $6.9(0.3)$ & 9 & $14.6(1.4)$ & $6.6(0.6)$ & \\
\hline 12 & $16.8(0.5)$ & $7.6(0.2)$ & 9 & $17 \cdot 6(2 \cdot 4)$ & $7 \cdot 9(1 \cdot 1)$ & 1 \\
\hline $15^{*}$ & & & & $22 \cdot 7(2 \cdot 2)$ & $10.2(1.0)$ & \\
\hline
\end{tabular}

$n$ refers to number of independent measurements with groups of fish. M ean values and S.D. (in parentheses) are given in $\mu \mathrm{mol} \mathrm{O}_{2}$ and J oule (J).

$*$ D ata from W ieser $\&$ M edgyesy (1990b).

were sampled at four dates in such a way that thermal age [expressed in day degrees (DD), after fertilization] was identical in the two acclimation groups, i.e. 360 (hatching), 515,630 and 690 . This corresponds to the following ages after hatching (in days): $5^{\circ} \mathrm{C}$ : $0,31,54,66 ; 10^{\circ} \mathrm{C}: 0,16,27,33$.

\section{HISTOLOGY AND MORPHOMETRY}

For light microscopy whole specimens were incubated in a formaldehydeglutaraldehyde fixative according to K arnowsky (1965) buffered with $0.05 \mathrm{M}$ sodium cacodylate at $\mathrm{pH} 7 \cdot 2$. From each sample to be studied (four dates at each of two temperatures) three specimens were cut transversely at the level of the anal region. It should be pointed out that in salmon no histological differences between somites were found in this region by $U$ sher et al. (1994). The posterior halves of the cut specimens were dehydrated in alcohol series up to $100 \%$ and embedded in K ulzer's Technovit 7100 cold-curing resin. Semithin sections $(3 \mu \mathrm{m})$ were cut on a R eichert 2030 rotation microtome and stained with a periodic acid methamine silver (PAM S) method according to the LKB M anual on Preparation Techniques and Plastic H istology. This staining method shows good specificity for the basal lamina and thus led to excellent contrast enhancement of the fibre outline. D igitizing was done by averaging 32 frames per image, followed by linear contrast stretching. Finally the biff-images with a dimension of $768 \times 512$ pixels and a pixel aspect ratio of $1: 1$ were converted into a suitable format (TIFF, IBM PC Byte Order) with the aid of a graphics file format converter (D eBabelizer, Equilibrium Technologies). Images were processed with an Apple $M$ acintosh Quadra 950 computer using the public domain image processing program $\mathrm{NIH}$ I mage (written by Wayne Rasband at the $\mathrm{N}$ ational Institutes of $\mathrm{H}$ ealth and available via I nternet by anonymous ftp from zippy.nimh.nih.gov or on floppy disc from NTIS, 5285 Port R oyal Rd, Springfield, VA 22161, part number PB93-504868) and a SCION LG-3 Frame Grabber card. Further processing required measuring cross sectional areas of the inner white fibres of the epaxonic musculature using the image analysis program OPTIM AS (Bio Scan, Incorporated, 170 W est Dayton, Suite 204, Edmonds, WA 98020). A s the staining method used led to a relatively clear separation of the muscle fibre cross sections from the surrounding material, most of the fibres were identified automatically in the multiple mode of the software package. To separate touching fibres, contrasts were enhanced further manually by drawing around single profiles in the retouch mode of OPTIMAS. 


\section{RESULTS}

\section{METABOLIC RATE}

Oxygen consumption was measured in spontaneously swimming yolk-sac and feeding larvae, the latter with guts evacuated. Thus the rates measured correspond to a routine or maintenance rate of energy metabolism $\left(R_{r}, R_{m}\right.$; see Wieser, 1995) (Table I). For the feeding larvae the results of previous measurements on the same species at $15^{\circ} \mathrm{C}$ have been added.

\section{GROWTH}

The variation in size of the fish studied is indicated by the following weight determinations [WBM in $\mathrm{mg}$, means \pm S.D. $(\mathrm{n})$ ]: at hatching (360 DD): $4^{\circ} \mathrm{C}$ : $6.0 \pm 0.52$ (15); $8^{\circ} \mathrm{C}: 6.0 \pm 0.75$ (15); after $690 \mathrm{D} \mathrm{D}: 5^{\circ} \mathrm{C}: 52.4 \pm 2.23$ (10); $10^{\circ} \mathrm{C}$ : $55 \cdot 3 \pm 1.49(10)$.

In the larvae acclimated to 5 and $10^{\circ} \mathrm{C}$ rates of growth were determined during three intervals between 360 and $690 \mathrm{DD}$ (corresponding to 66 and 33 days after hatching at 5 and $10^{\circ} \mathrm{C}$ respectively). The average relative rates of growth in these two groups were $3.5 \pm 1.7$ and $7.6 \pm 2.1 \%$ day $^{-1}$ at 5 and $10^{\circ} \mathrm{C}$ respectively. In the larvae acclimated to $12^{\circ} \mathrm{C}$ the rate of growth was determined only once during the interval between hatching and 648 DD (24 days), yielding a value of $9 \cdot 4 \%$ day $^{-1}$. Since dry body mass (D BM ) of the larvae represented a constant proportion of wet body mass (WBM) irrespective of temperature ( $D B M=0.19$ W BM $; r=0.995, n=185$ ), the growth rates determined apply to both expressions of body mass.

\section{GROWTH OF MUSCLE FIBRES, MORPHOMETRY}

A s in other species, the larvae of whitefish at hatching possess a single layer of small-diameter muscle fibres which is present beneath almost the entire surface of the skin (superficial muscle fibres: Batty, 1984; red layer: El-Fiky et al., 1987). The fibres of this layer are densely packed with mitochondria, causing the contractile filaments to form a loose, irregular pattern ( $\mathrm{H}$ anel, 1995). The space between the red layer and the central organs is filled by the inner muscle fibres (R aamsdonk et al., 1978), packed with contractile filaments, which will develop into the typically glycolytic white fibres of adult fish. In the larvae both the outer and the inner muscle fibres contain more mitochondria than the corresponding fibres of juveniles and adults, attesting to the predominantly aerobic nature of larval metabolism (W ieser, 1995).

In agreement with findings in other species the differentiation of the inner muscle fibres of $\mathrm{C}$. lavaretus is clearly influenced by the rearing temperature (Stickland et al., 1988; Vieira \& J ohnston, 1992; Brooks \& J ohnston, 1993; J ohnston, 1993; U sher et al., 1994). In the course of development the muscle mass increases either by the generation of new fibres from myogenic cells (hyperplasia) or by mass increase of the old fibres (hypertrophy). The increase in cross sectional area of the swimming muscles during development can be illustrated by plotting fibre area against fibre number. Figures 1 and 2 give an impression of the relationship between hyperplasia and hypertrophy at hatching of embryos of whitefish incubated for $360 \mathrm{DD}$ at 4 and $8^{\circ} \mathrm{C}$, and of the larvae after being maintained for another $330 \mathrm{DD}$ at 5 and $10^{\circ} \mathrm{C}$. Incubation 

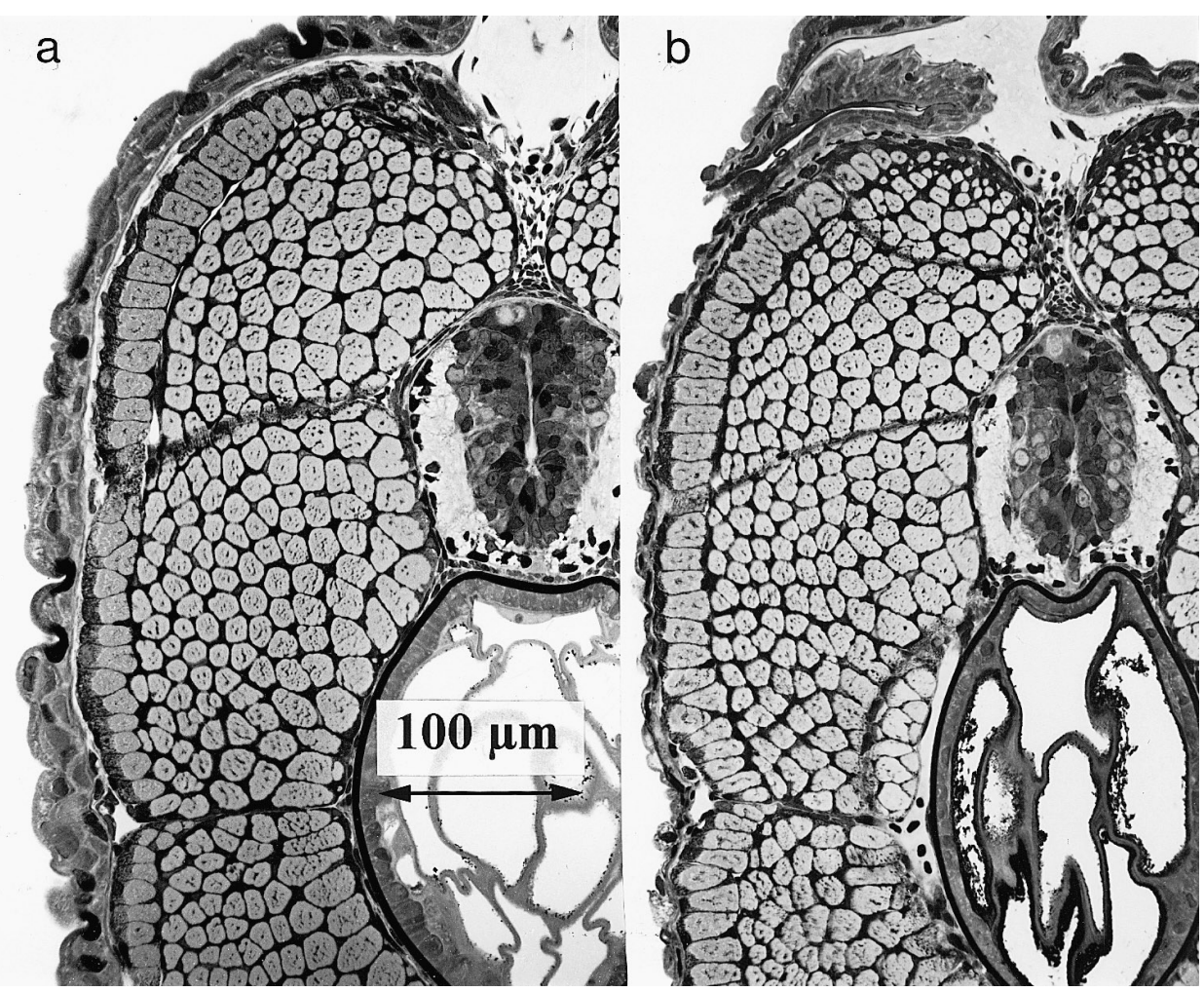

F IG. 1. Transverse sections of one quadrant of epaxial muscles in larvae of $C$. lavaretus, 1 day after hatching, reared at (a) $8^{\circ} \mathrm{C}$ or (b) $4^{\circ} \mathrm{C}$. Fish were fixed in $\mathrm{K}$ arnowsky, semithin $(3 \mu \mathrm{m})$ sections stained with periodic acid methamine silver (PAMS).

temperature had a considerable influence on fibre differentiation up to the end of the yolk-sac period of the embryos. A t hatching, average cross-sectional area of the inner muscle fibres was $92.2 \pm 7.4$ and $112.8 \pm 4.4 \mu \mathrm{m}^{2}$ in the $4-$ and $8^{\circ} \mathrm{C}$-acclimated groups respectively. The total number of fibres in the middle of the larval body was $827 \pm 48$ and $657 \pm 61$ in the two groups $(n=3)$ (Table III). The total cross-sectional area in the two groups of larvae was nearly identical at hatching, i.e. 0.076 and $0.074 \mathrm{~mm}^{2}$, but hyperplasia contributed more to the increase of muscle mass in the cold-acclimated than in the warm-acclimated fish.

In contrast to the events during embryonic development, in the free feeding larvae the muscle fibres of the cold-acclimated group experienced a boost in mass increase (hypertrophy), those of the warm-acclimated group a boost in the increase of fibre number (hyperplasia). A fter $330 \mathrm{DD}$, that is 66 and 33 days after hatching at 5 and $10^{\circ} \mathrm{C}$ respectively, the total cross sectional area of muscle fibres increased about tenfold but was similar $\left(0.76\right.$ and $\left.0.80 \mathrm{~mm}^{2}\right)$ in the fish acclimated to the two experimental temperatures.

\section{SOMATIC PRODUCTION AND POWER BUDGETS}

On the basis of the determination of body mass of larvae acclimated to 5,10 and $12^{\circ} \mathrm{C}$ somatic production at three temperatures can be calculated for larvae between hatching and approximately $690 \mathrm{DD}$ after fertilization. By means of 
(a) $\mathrm{T}_{1}$
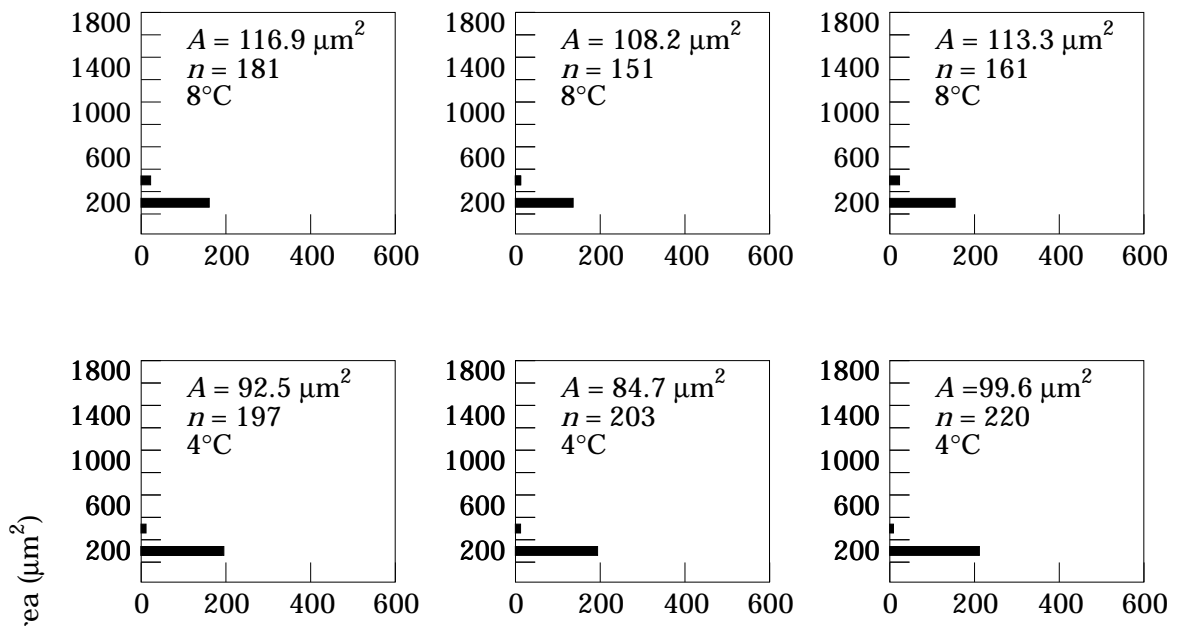

(b) $\mathrm{T}_{2}$
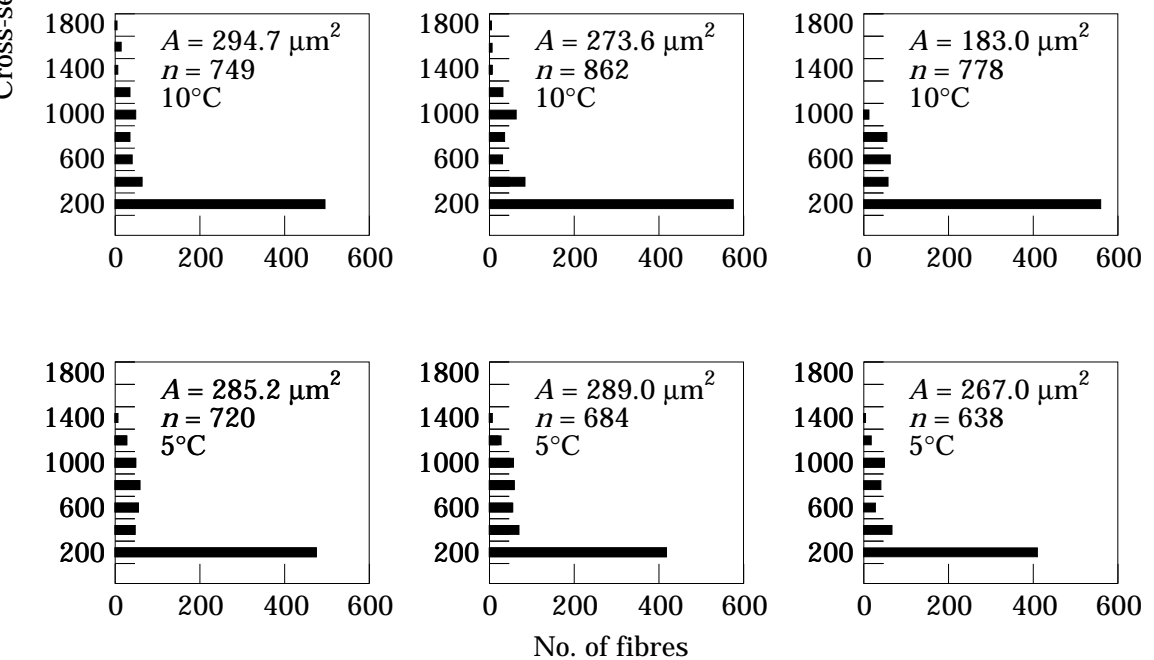

F IG. 2. Cross-sectional area and number per quadrant of inner muscle fibres in larvae of $C$. lavaretus reared at two temperatures. Two developmental stages are compared, each represented by three specimens: (a) $T_{1}, 1$ day after hatching; (b) $T_{2}, 330$ day degrees after hatching (for further details see Table II). M eans of cross-sectional area $(A)$ and number of fibres per quadrant $(n)$ indicated for each specimen.

the two relationships: $D B M=0.19 \mathrm{WBM}$, and $1 \mathrm{mgDBM}=22.7 \mathrm{~J}$ (W ieser $\&$ M edgyesy, 1990b), mass production can be converted to rate of energy deposition. A second rate of growth can be calculated by measuring the muscle cross-sectional area at $\mathrm{T}_{1}$ and $\mathrm{T}_{2}$ (T able II) and calculating the rate of increase of this variable. If the changes occurring in the body region at which the cross sections were taken are considered to be representative of the changes in the whole body, the rate of increase of muscle cross sectional area corresponds to the rate of increase of total muscle mass. The fact that the two rates of growth 
TABLE II. A spects of the differentiation of the central muscle mass and of growth in early larvae of $\mathrm{C}$. lavaretus at three temperatures

\begin{tabular}{|c|c|c|c|}
\hline Variable & (4) $5^{\circ} \mathrm{C}$ & (8) $10^{\circ} \mathrm{C}$ & (8) $12^{\circ} \mathrm{C}$ \\
\hline \multicolumn{4}{|l|}{$\mathrm{T}_{1}$} \\
\hline $\begin{array}{l}\text { Day degrees } \\
\text { Fibre cross section }\left(\mu m^{2}\right)(A) \\
\text { No. of fibres }(n)\end{array}$ & $\begin{array}{l}360 \\
92 \cdot 2 \\
827\end{array}$ & $\begin{array}{l}360 \\
112 \cdot 7 \\
657\end{array}$ & c. 360 \\
\hline$A \times n\left(m^{2}\right)$ & 0.076 & 0.074 & \\
\hline WBM (mg) & 6 & 6 & $5 \cdot 5$ \\
\hline Total length $\left(I_{t}\right)$ & 11 & 11 & \\
\hline \multicolumn{4}{|l|}{$\mathrm{T}_{2}$} \\
\hline $\begin{array}{l}\text { D ay degrees } \\
\text { F ibre cross section }\left(\mu m^{2}\right)(A)\end{array}$ & $\begin{array}{l}690 \\
280\end{array}$ & $\begin{array}{l}690 \\
251\end{array}$ & C. 648 \\
\hline No. of fibres $(n)$ & 2723 & 3185 & \\
\hline$A \times n\left(m^{2}\right)$ & 0.76 & 0.80 & \\
\hline WBM (mg) & $52 \cdot 4$ & $55 \cdot 3$ & $47 \cdot 6$ \\
\hline Total length $\left(I_{t}\right)$ & $23 \cdot 3$ & 23 & \\
\hline \multicolumn{4}{|l|}{$\mathrm{T}_{1} \rightarrow \mathrm{T}_{2}$} \\
\hline D ay degrees & 330 & 330 & c. 288 \\
\hline $\begin{array}{l}\text { D ays } \\
\Delta \mathrm{A}\left(\mathrm{mm}^{2} \mathrm{day}^{-1}\right)\end{array}$ & $\begin{array}{l}66 \\
0.0104\end{array}$ & $\begin{array}{l}33 \\
0.022\end{array}$ & \\
\hline$\triangle \mathrm{WBM}(\mathrm{mg})$ & $46 \cdot 4$ & $49 \cdot 3$ & $42 \cdot 1$ \\
\hline$\triangle \mathrm{DBM}(\mathrm{mg})$ & $9 \cdot 2$ & $9 \cdot 8$ & $8 \cdot 4$ \\
\hline $\mathrm{J} \mathrm{day}^{-1}(1 \mathrm{mg} \mathrm{DBM}=22 \cdot 7 \mathrm{~J})$ & $3 \cdot 16$ & $6 \cdot 74$ & $7 \cdot 9$ \\
\hline A verage WBM (g) & 0.023 & 0.0245 & 0.0211 \\
\hline$P_{\text {som }}\left(J g W B M M^{-1} h^{-1}\right)$ & $5 \cdot 56$ & $11 \cdot 1$ & $15 \cdot 2$ \\
\hline$\Delta \mathrm{l}_{\mathrm{t}}(\mathrm{mm})$ & $12 \cdot 3$ & $12 \cdot 0$ & \\
\hline I. day $^{-1}(\mathrm{~mm})$ & 0.186 & $0 \cdot 364$ & \\
\hline$R_{g}\left(J g W B M-1 h^{-1}\right)$ & $1 \cdot 70$ & 3.41 & $4 \cdot 67$ \\
\hline
\end{tabular}

The eggs of the larvae observed at 5 and $10^{\circ} \mathrm{C}$ had developed at 4 and $8^{\circ} \mathrm{C}$ respectively and hatched at 360 day degrees (DD) $\left(T_{1}\right)$. The eggs of the larvae observed at $12^{\circ} \mathrm{C}$ had developed at $8{ }^{\circ} \mathrm{C}$ and were transferred to the new temperature at hatching. In this batch the number of DD after fertilization can only be approximated, but in the other two batches the observation period ended after $690 \mathrm{DD}\left(\mathrm{T}_{2}\right)$. The histological data are mean values (individual values given in Fig. 2) of three, the morphological data of $10-15$, specimens, at each of the two sampling dates.

Cost of growth $\left(R_{g}\right)$ calculated on the basis of the calibration curve in Wieser (1994).

calculated $\left(\triangle \mathrm{A}\right.$ and $\mathrm{P}_{\text {som }}$ in Table II) are very similar proves the validity of this assumption. An estimate of the contribution of production to the total energy budget of the larvae requires an estimate of the metabolic cost of growth. This is possible by using the empirical calibration curve recently published (Wieser, 1994) which yields a metabolic ' work load ' of approximately $15 \mu \mathrm{mol} \mathrm{O}_{2}$ for the deposition of $1 \mathrm{mgDBM}$ with a caloric value of about $22 \mathrm{~J}$. The data required for the calculation of the rates of production processes in larvae of $\mathrm{C}$. lavaretus at three temperatures are summarized in Table II, $T_{1}$ referring to the time of hatching of all groups of fish at about $360 \mathrm{DD}, \mathrm{T}_{2}$ to the end of the experiment approximately $288\left(12^{\circ}\right)$ and $330\left(5,10^{\circ} \mathrm{C}\right) \mathrm{DD}$ after hatching.

By converting metabolic expenditures and growth to the same units (J g WBM ${ }^{-1} h^{-1}$ ) a power budget for small larvae can be constructed (Table III). There are two components of metabolic expenditures: (1) the routine 
TABLE III. Power budgets (unit: J $\mathrm{g} \mathrm{WBM}^{-1} \mathrm{~h}^{-1}$ ) of larvae of $\mathrm{C}$. lavaretus between approximately 360 (hatching) and 690 D D after fertilization (see Table II for details) at three experimental temperatures

\begin{tabular}{lcccccc}
\hline F unction & $5^{\circ} \mathrm{C}$ & $\%$ & $10^{\circ} \mathrm{C}$ & $\%$ & $12^{\circ} \mathrm{C}$ & $\%$ \\
\hline $\mathrm{R}_{\mathrm{r}}$ & $4 \cdot 8$ & $(74)$ & $6 \cdot 6$ & $(66)$ & $7 \cdot 9$ & $(63)$ \\
$\mathrm{R}_{\mathrm{g}}$ & $1 \cdot 7$ & $(26)$ & 3.4 & $(34)$ & $4 \cdot 7$ & $(37)$ \\
$\mathrm{R}_{\text {tot }}$ & $6 \cdot 5$ & $(100)$ & $10 \cdot 0$ & $(100)$ & $12 \cdot 6$ & $(100)$ \\
$\mathrm{P}_{\text {som }}$ & $5 \cdot 6$ & $46 \cdot 3$ & $11 \cdot 1$ & $47 \cdot 4$ & & $45 \cdot 3$ \\
$\mathrm{C}_{\mathrm{m}}$ & $12 \cdot 1$ & 100 & $21 \cdot 1$ & 100 & $15 \cdot 2$ & $54 \cdot 7$ \\
\hline
\end{tabular}

R elative values (\%) are based either on $C_{m}$ or on $R_{\text {tot }}$, the latter in parentheses. The ratio $P_{\text {som }} / C_{m}$ represents the net growth efficiency $\left(K_{2}\right)$. $R_{r}$, R outine rate of metabolism; $R_{g}$, cost of growth (see Table II); $R_{\text {tot }}$, total metabolic expenditures; $P_{\text {som }}$ growth; $C_{m}$, metabolizable food energy, i.e. $R_{\text {tot }}+P_{\text {somi }}$; WBM, wet body mass.

or maintenance rate $\left(R_{r}\right)$ of spontaneously swimming, non-feeding, non-growing larvae as summarized in Table I; (2) the cost of growth, i.e. the metabolic expenditures connected with the deposition of body mass in larvae fed ad libitum $\left(R_{g}\right)$. This component has been calculated on the basis of the rates of growth $\left(P_{\text {som }}\right)$ (Table II) and the calibration curve in W ieser (1994). Between 5 and $12^{\circ} \mathrm{C}$ both $P_{\text {som }}$ and $R_{r}$ increased with temperature (Fig. 3, Table III), but the power invested in the form of body mass increased more steeply than the power expended in maintenance metabolism. This divergence resulted in an increase in net production efficiency, i.e. $P_{\text {som }} /\left(P_{\text {som }}+R_{\text {tot }}\right) \times 100$, from about $46 \%$ at $5^{\circ} \mathrm{C}$ to about $55 \%$ at $12^{\circ} \mathrm{C}$.

\section{EFFECTS OF TEMPERATURE ON DIFFERENT BIOLOGICAL FUNCTIONS}

The data summarized in Tables I-III allow the determination of temperature coefficients ( $Q_{10}$-values) of the following biological functions: (1) metabolic rates; (2) rate of muscle growth based on the morphometry of muscle fibres as presented in Fig. 2; (3) rate of body growth $\left(\mathrm{P}_{\text {som }}\right)$. Somatic production increases with temperature more steeply than rate of metabolism (Table IV) - with the exception, of course of $R_{g}$ which is directly proportional to $P_{\text {som }}$. It is reassuring that two completely different methods for the determination of production, the calculation of muscle cross sectional area from histological sections, and the determination of body weight, led to approximately the same $Q_{10}$-value of about 4.0 , more than twice the value for the maintenance rate of metabolism.

\section{DISC USSION}

Our data contribute to two aspects of the temperature relationships of fish: the effect of acclimation temperature on growth efficiency and energy allocation; and the effect of rearing temperature on muscle growth (' tissue cellularity ').

The literature suggests that gross growth efficiency $\left(K_{1}\right)$ is temperature independent in the larvae of fish (Paloheimo \& Dickie, 1966; Houde, 1989; Houde \& Zastrow, 1993), whereas in juveniles and adults $\mathrm{K}_{1}$ increases with temperature up to a critical threshold (Elliott, 1976; Brett, 1979; Brett \& G roves, 

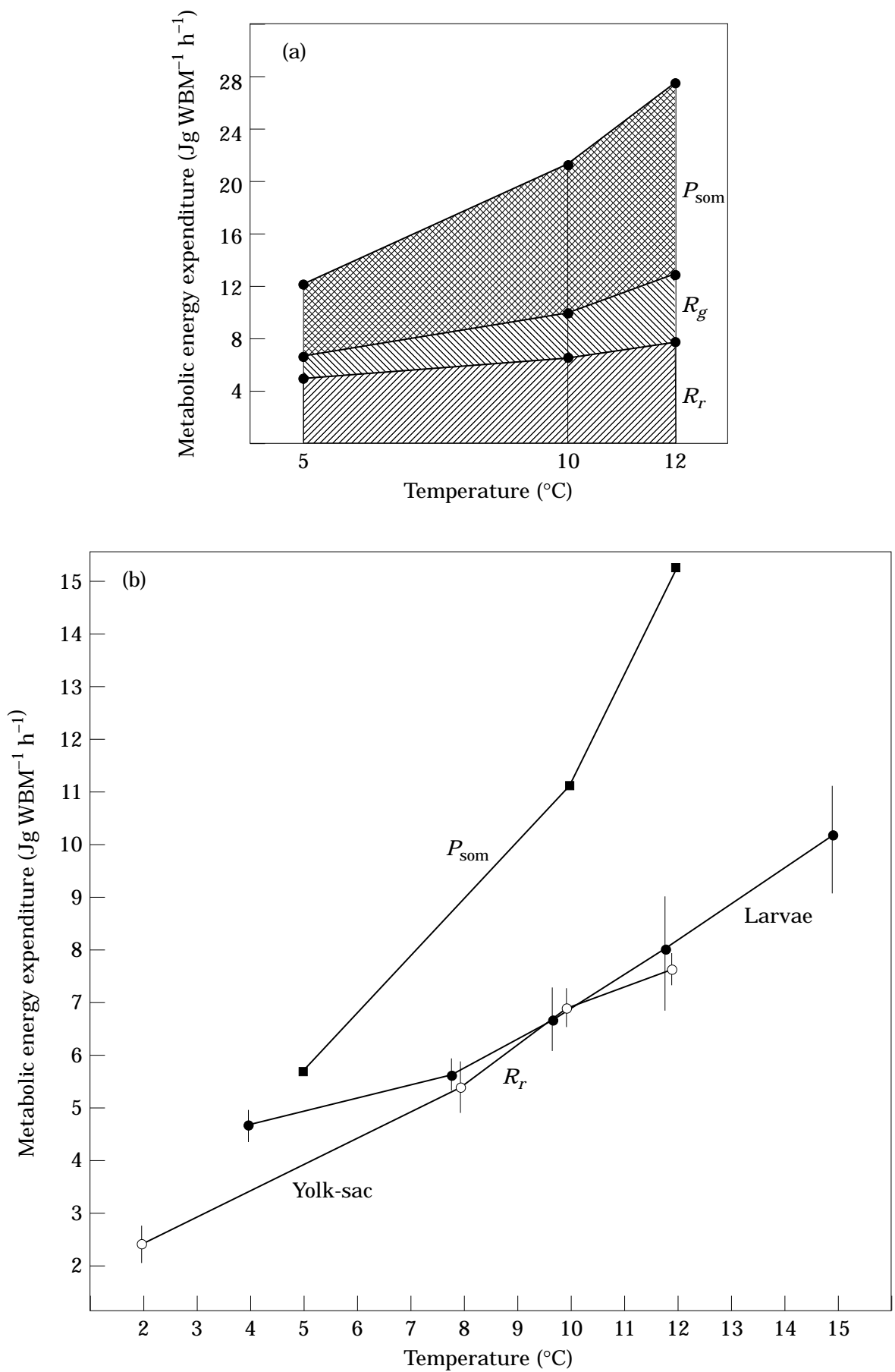

F IG. 3. M etabolic energy expenditures and somatic production $\left(P_{\text {som }}\right)$ in larvae of $C$. lavaretus at a range of temperatures. Oxygen consumption and growth expressed in energy equivalents, based on the following conversion factors: $1 \mathrm{mg} \mathrm{DBM}=22.7 \mathrm{~J} ; 1 \mu \mathrm{mol} \mathrm{O}_{2}=0.45 \mathrm{~J}$. The energy budget (a) is based on the two sampling dates termed $T_{1}$ and $T_{2}$ in Table II. $R_{r}$, R outine rate of metabolic activity; $R_{g}$, metabolic cost of growth, calculated on the basis of growth rates by means of the calibration curve in W ieser (1994). 
TABLE IV. $Q_{10}$-values for two temperature intervals of rates of change of physiological and morphological variables in larvae of C. lavaretus between approximately 360 (hatching) and 650-690 D D after fertilization (see Table II for details)

\begin{tabular}{|c|c|c|}
\hline \multirow{2}{*}{ Variable (dimension) } & \multicolumn{2}{|c|}{$\mathrm{R}$ ange of temperature $\left({ }^{\circ} \mathrm{C}\right)$} \\
\hline & $5 \rightarrow 10$ & $10 \rightarrow 12$ \\
\hline 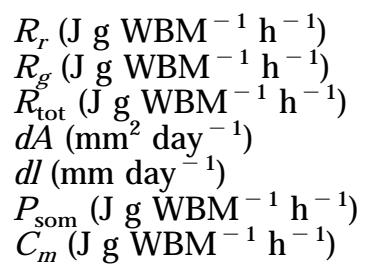 & $\begin{array}{l}1 \cdot 8 \\
4 \cdot 02 \\
2 \cdot 3 \\
4 \cdot 47 \\
3 \cdot 8 \\
4 \cdot 0 \\
3 \cdot 0\end{array}$ & $\begin{array}{l}2 \cdot 45 \\
4 \cdot 8 \\
3 \cdot 1\end{array}$ \\
\hline
\end{tabular}

A bbreviations as in Table III; in addition: A, total cross-sectional area of inner muscle fibres; I, total length.

1979; W ootton, 1990; J obling, 1994). This difference is almost certainly due to the delayed development of the digestive apparatus in fish. In larvae the gut is still short and straight, a feature accompanied by poor feeding performance, fast evacuation rates ( $\mathrm{K}$ amler, 1992) and a general tendency of losing digestive enzymes with the faeces (H ofer \& $N$ asir $U$ ddin, 1985; K öck \& H ofer, 1989). In consequence, fish larvae may always have to operate close to maximum digestive capacity and be less flexible in their responses to variations in food availability than older fish. This is also reflected in the indirect proportionality between assimilation efficiency and water temperature in marine larvae (H oude, 1989).

H owever, once food energy has been absorbed, fish larvae appear to be quite flexible in their ability to allocate metabolizable energy to different body functions according to priority of demand. This explains the pattern of energy allocation during periods of fast growth (Wieser, 1994) and is evident from the results of the present investigation which showed $R_{r}$ to increase with a temperature coefficient of from 1.8 to 2.45 whereas $P_{\text {som }}$ increased with a temperature coefficient of from 4.0 to 4.8 resulting in an increase of $K_{2}$ from $46.3 \%$ at $5^{\circ} \mathrm{C}$ to $54.7 \%$ at $12^{\circ} \mathrm{C}$ (Table III). A similar ratio of increase has been found by $\mathrm{H}$ oude (1989) in marine fish, i.e. from $37 \%$ at $10^{\circ} \mathrm{C}$ to $48 \%$ at $30^{\circ} \mathrm{C}$. A higher net conversion efficiency but with a similar temperature coefficient has been reported for Rutilus rutilus (L.) by Wieser et al. (1988). In embryos of Oncorhynchus mykiss (Walbaum) reared at 9 and $14^{\circ} \mathrm{C}, \mathrm{K}$ amler (1992) found developmental processes to proceed with a $Q_{10}$-value of approximately 3.0 whereas metabolic expenditures were almost temperature independent $\left(Q_{10}=1.03-1.07\right)$. As far as first-feeding larvae are concerned it should be pointed out, however, that the correct determination of $\mathrm{K}_{2}$ requires inclusion in the energy budget of the ' cost of growth ' $\left(R_{g}\right)$. The present paper is one of the few in which this has been done for fish larvae (see also W ieser \& M edgyesy, 1990a,b).

The hypothesis presented here is still quite speculative, resting on circumstantial evidence. If corroborated by more studies directed towards the analysis of defined populations it would present yet another example for the ontogenetic 


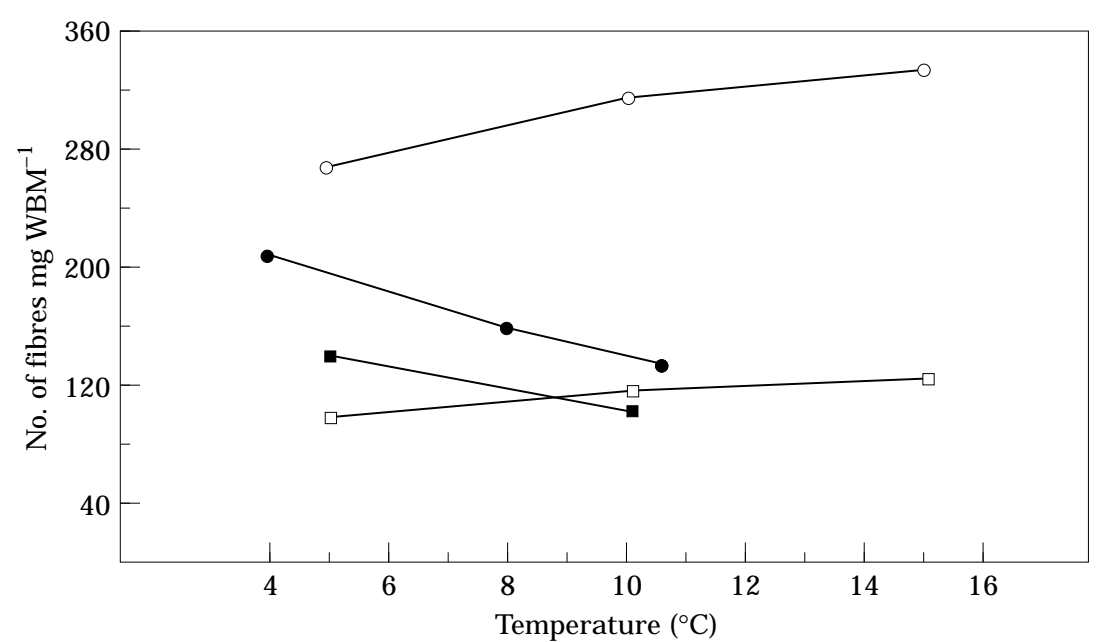

F IG. 4. R elationship between mass-specific fibre number and rearing temperature in larvae of four species of teleosts, 1 day after hatching. D ata based on the following references: plaice (P. platessa, $O)$, Brooks \& Johnston, 1993, estimated body weight $1.5 \mathrm{mg}$; herring ( $C$. harengus, $\square$ ), values represent averages of two investigations, Vieira \& J ohnston, 1992 and J ohnston, 1993, estimated body weight 2.3 mg; salmon (S. salar, ), Stickland et al. (1988) and U sher et al. (1994), estimated body weight $22 \mathrm{mg}$; white fish (C. lavaretus, $\mathbf{0})$, this investigation, body weight $6 \mathrm{mg}$. Body weights estimated on the basis of the total length measurements given in the references.

discontinuity marking the transition from the larval to the juvenile life stage in fish (W ieser, 1995).

R ecent studies have shown that water temperature influences the process of differentiation of the swimming muscles (Stickland et al., 1988; Vieira \& J ohnston, 1992; J ohnston, 1993; Brooks \& J ohnston, 1993; U sher et al., 1994). The major point emerging from these studies is that the two pathways leading to an increase of muscle mass, i.e. hypertrophy (increase of mass of individual fibres) and hyperplasia (increase of number of fibres) are differentially affected by temperature during embryonic development. In embryos reared at different temperatures total muscle mass at hatching is more or less independent of temperature. However, at one temperature the final mass may owe more to hypertrophy, at another temperature it may owe more to hyperplasia. Curiously, however, in the four species investigated so far temperature exerted opposite effects of muscle growth in the embryos (Blaxter, 1992): in plaice Pleuronectes platessa $L$., and herring Clupea harengus $L$. the lower temperature stimulated hypertrophy, the higher temperature hyperplasia, whereas in salmon Salmon salar L. and whitefish, the object of the present study, the opposite was the case (Fig. 4).

U sher et al. (1994), referring to a paper by Cheek \& Hill (1970), put forward the following explanation based on energetic considerations of the finding that hyperplasia prevailed at the lower temperature: (1) in eggs provided with a fixed amount of energy supply in the form of yolk, the energy above maintenance expenditures is potentially available for biochemical syntheses; (2) since metabolic expenditures are positively related to temperature the scope for growth and differentiation may be greater at low than at high temperatures; (3) thus at low 
temperatures the more expensive process of hyperplasia, requiring both protein synthesis and nuclear divisions, may be favoured, whereas at high temperatures hypertrophy, requiring only protein synthesis, would be the ontogenetic strategy of choice. This is a speculative suggestion which, however, is in line with the old observation that other meristic characters, particularly the number of vertebrae, show the same trend-numbers decrease with increasing temperature ( $G$ arside, 1970).

No explanation is readily available for the opposite case, the increase of fibre number with temperature, as observed in plaice and herring. H owever, the fact that we found the freshwater species $C$. lavaretus to display the same morphometric response to temperature as the other freshwater-derived species, $\mathrm{S}$. salar, allows us to speculate that the response of the two marine species, $P$. platessa and C. harengus, may be related to the presence of large amounts of free amino acids in their eggs serving both as osmotic effectors and energy source (Fyhn \& Serigstad, 1987; Thorsen et al., 1993; Finn, 1994). If free amino acids provide a quantitatively significant source of easily available nutrients this might counteract the constraints on anabolic processes at higher temperatures characteristic of eggs without such an additional source of energy. This speculation is supported by two observations: firstly, that in free-feeding larvae and juveniles the constraint of high temperature on anabolic processes disappears, faster growth being associated with fibre hyperplasia (W eatherley \& G ill, 1987; H iggins $\&$ Thorpe, 1990; Fig. 2 and Table II of the present paper); secondly, that in certain trout hybrids characterized by eggs with a much reduced yolk volume, the number of myomeres in the embryos at hatching is also reduced ( $\mathrm{G}$ arside \& Fry, 1959).

This research has been supported by the $F$ onds zur $F$ örderung der wissenschaftlichen Forschung in Österreich project no. P10237-BIO. We thank D r H. Forstner and W. Salvenmoser for advice and technical assistance in connection with the morphometric and histological aspects of this work.

\section{R eferences}

Batty, R. S. (1984). D evelopment of swimming movements and musculature of larval herring (Clupea harengus). J ournal of Experimental Biology 110, 217-229.

Blaxter, J. H. S. (1992). The effect of temperature on larval fishes. N etherlands J ournal of Zoology 42, 336-357.

B rett, J. R . (1976). Scope for metabolism and growth of sockeye salmon, O ncorhynchus nerka, and some related energetics. J ournal of the Fisheries R esearch Board of Canada 33, 307-313.

Brett, J. R. (1979). Environmental factors and growth. In Fish Physiology, Vol. VIII (Hoar, W. S., R andall, D. J. \& Brett, J. R., eds), pp. 599-677. N ew Y ork: A cademic Press.

Brett, J. R . \& Groves, T. D. D. (1979). Physiological energetics. In Fish P hysiology, Vol. VIII (H oar, W. S., R andall, D. J . \& Brett, J. R ., eds), pp. 280-352. N ew Y ork: A cademic Press.

Brooks, S. \& J ohnston, I. A. (1993). Influence of development and rearing temperature on the distribution, ultrastructure and myosin sub-unit composition of myotomal muscle-fibre types in the plaice Pleuronectes platessa. Marine Biology 117, 501-513.

Cheek, D. B. \& Hill, D. E. (1970). M uscle and liver cell growth: role of hormones and nutritional factors. Federation P roceedings 29, 1503-1509. 
El-F iky, N ., H interleitner, S. \& Wieser, W. (1987). Differentiation of swimming muscles and gills, and development of anaerobic power in the larvae of cyprinid fish (Pisces, Teleostei). Z oomorphology 107, 126-132.

Elliott, J. M . (1976). The energetics of feeding, metabolism and growth of brown trout (Salmo trutta L.) in relation to body weight, water temperature and ration size. J ournal of A nimal Ecology 45, 923-948.

Finn, R. N. (1994). Physiological energetics of developing marine fish embryos and larvae. Thesis, U niversity of Bergen.

Forstner, H. (1983). A n automatic multiple-chamber intermittent-flow respirometer. In Polarographic Oxygen Sensors (G naiger, E. \& Forstner, H., eds), pp. 111-126. Berlin: Springer.

Fyhn, H.J . \& Serigstad, B. (1987). F ree amino acids as energy substrate in developing eggs and larvae of the cod, Gadus morhua. M arine Biology 96, 335-341.

Garside, E. T. (1970). Structural responses. In M arine Ecology, Vol. I (K inne, O., ed.), pp. 561-573. L ondon: Wiley-Interscience.

Garside, E. T. \& Fry, F. E. J. (1959). A possible relationship between yolk size and differentiation in trout embryos. Canadian J ournal of Z oology 37, 383-386.

$\mathrm{H}$ anel, R . (1995). U ntersuchungen zur W irkung der W assertemperature auf Wachstum und Entwicklung der Axialmuskulatur bei frühen Entwicklungsstadien des Bodensee-G angfisches (Caregonus lavaretus macrophthalmus). Diplomarbeit (M aster Thesis), D epartment of Zoology, U niversity of Innsbruck.

Higgins, P. J \& \& Thorpe, J. E. (1990). H yperplasia and hypertrophy in the growth of skeletal muscle in juvenile A tlantic salmon, Salmo salar L. J ournal of Fish Biology 37, 505-519.

H ofer, R . \& N asir U ddin, A. (1985). Digestive processes during the development of the roach, $R$ utilus rutilus $L$. J ournal of Fish Biology 26, 683-689.

Houde, E. D. (1989). Comparative growth, mortality, and energetics of marine fish larvae: temperature and implied latitudinal effects. Fishery Bulletin of the United States 87, 471-495.

H oude, E . D . \& Zastrow, C. E . (1993). E cosystem- and taxon-specific dynamic and energetics properties of larval fish assemblages. Bulletin of M arine Science 53, 290-335.

Ivlev, V. S. (1945). Biologicheskaya produktivnost' vodoemov. English translation: The biological productivity of waters. J ournal of the Fisheries Research Board of Canada 23, 1727-1759.

J obling, M. (1994). Fish Bioenergetics. L ondon: Chapman \& $\mathrm{H}$ all.

Johnston, I. A . (1993). Temperature influences muscle differentiation and the relative timing of organogenesis in herring (Clupea harengus) larvae. M arine Biology 116, 363-379.

K amler, E. (1992). Early Life H istory of Fish. London: Chapman \& Hall.

K arjalainen, J., K oho, J. \& Viljanen, M. (1991). The gastric evacuation rate of vendace (Coregonus albula L.) larvae predating on zooplankters in the laboratory. A quaculture 96, 343-351.

K arnowsky, M . J . (1963). A formaldehyde-glutaraldehyde fixative of high osmolarity for use in electron microscopy. J ournal of Cell Biology 27, 137A-138A .

K öck, G.\& Hofer, R. (1989). The effect of natural and artificial diets upon tryptic activity of roach (Rutilus rutilus) and whitefish (Coregonus sp.) larvae. Polskie A rchivum $\mathrm{H}$ ydrobiologii 36, 443-453.

Paloheimo, J. E. \& Dickie, L. M. (1966). Food and growth of fishes. III. R elations among food, body size, and growth efficiency. Journal of the Fisheries R esearch B oard of Canada 23, 1209-1248.

Stickland, N . C., White, R. N ., M escall, P. E., Crook, A. R.\& Thorpe, J . E. (1988). The effect of temperature on myogenesis in embryonic development of the $A$ tlantic salmon (Salmo salar L.). A natomy and E mbryology 178, 253-257.

Thorsen, A ., F yhn, H . J \& \& W allace, R . A . (1993). F ree amino acids as osmotic effectors for oocyte hydration in marine fishes. In Physiological and Biochemical A spects of Fish Development (Walther, B. T. \& Fyhn, H. J., eds), pp. 94-98. Bergen: U niversity of Bergen. 
U sher, M . L., Stickland, N. C. \& Thorpe, J. E. (1994). M uscle development in A tlantic salmon (Salmo salar) embryos and the effect of temperature on muscle cellularity. J ournal of Fish Biology 44, 953-964.

van R aamsdonk, W., Pool, C. W. \& te K ronnie, G. (1978). Differentiation of muscle fibre types in the teleost Brachydanio rerio. A natomy and Embryology 153, 137-155.

Vieira, V. L. A. \& Johnston, I. A . (1992). Influence of temperature on muscle-fibre development in larvae of the herring Clupea harengus. M arine Biology 112, 333-341.

Weatherley, A. H . \& G ill, H. S. (1987). The Biology of Fish Growth. London: A cademic Press.

Wieser, W. (1973). Temperature relations of ectotherms: a speculative review. In Effects of Temperature on Ectothermic Organisms (Wieser, W., ed.), pp. 1-24. Berlin: Springer.

W eiser, W. (1994). Cost of growth in cells and organisms: general rules and comparative aspects. B iological R eviews 68, 1-33.

W ieser, W. (1995). Energetics of fish larvae, the smallest vertebrates. A cta P hysiologica Scandinavica 154, 279-290.

Wieser, W.\& M edgyesy, N. (1990a). A erobic maximum for growth in the larvae and juveniles of a cyprinid fish, R utilus rutilus ( $L$.): implications for energy budgeting in small poikilotherms. Functional E cology 4, 233-242.

Wieser, W. \& M edgyesy, N. (1990b). Cost and efficiency of growth in the larvae of two species of fish with widely differing metabolic rates. Proceedings of the R oyal Society of L ondon B 242, 51-56.

W ieser, W., F orstner, H., Schiemer, F . \& M ark, W. (1988). G rowth rates and growth efficiencies in larvae and juveniles of Rutilus rutilus and other cyprinid species: Effects of temperature and food in the laboratory and in the field. Canadian $J$ ournal of Fisheries and A quatic Sciences 45, 943-950.

Wootton, R. J . (1990). E cology of Teleost Fishes. London: Chapman \& Hall. 